\title{
PRODUKSI SERUM Rabbit Anti-Catfish TERHADAP PENYAKIT Motile Aeromonas Septicemia (MAS) PADA IKAN PATIN SIAM (Pangasius hypophthalmus)
}

\section{SERUM RABBIT PRODUCTIONANTI-CATFISHOF MotileAeromonas Septicemia(MAS) DISEASEINPATINSIAMESE(Pangasius hypophthalmus)}

\author{
M. Bunyamin 1, Mulyana 1, Angela M. Lusiastuti ${ }^{2}$ \\ ${ }^{1}$ Jurusan Perikanan, Fakultas Pertanian, Universitas Djuanda Bogor, Jl. Tol Ciawi No. 1, Kotak Pos 35 \\ Ciawi, Bogor 16720. \\ ${ }^{2}$ Balai Penelitian dan Pengembangan Budidaya Air Tawar (BPPBAT) Bogor, Jl. Sempur No.1 Kota \\ Bogor.
}

\begin{abstract}
ABSTRAK
Penelitian mengenai produksi serum Rabbit Anti-Catfish dengan konsentrasi terbaik telah dilakukan untuk mendeteksi bakteri Aeromonas hydrophila pada ikan patin siam (Pangasius hypophthalmus) menggunakan metode ELISA. Serum ikan patin diambil melalui venacaudaliskemudian diinjeksikan secara sub kutan pada kelinci New Zealand White. MetodeELISA yang digunakan adalah metode indirect dan dilakukan untuk memperoleh konsentrasi RAC yang tepat menggunakan 2 jenis Antigen (Ag) A. hydrophila yang berbeda yaitu berupa pelet dan supernatan. Perbandingan konsentrasi RAC yang digunakan yaitu $1: 50,1: 100,1: 200,1: 500,1: 1000,1: 5000$. Parameter yang diamati yaitu konsentrasi total protein serum dan serum yang sudah didialisis pada darah ikan patin dan darah kelinci. Hasil penelitian menunjukkan bahwa perbandingan antara RAC dengan PBS-T yang menghasilkan konsentrasi pengenceran terbaik yaitu 1:5000 untuk antigen pelet dan 1:200 untuk antigen supernatan.
\end{abstract}

Kata Kunci: ELISA, serum, rabbit anti-Catfish, ikan Patin, Pangasius hypophthalmus

\section{ABSTRACT}

Research on the production of serum Rabbit Anti-Catfish with the best concentration was performed to detect the bacterium Aeromonas hydrophila in Siamese catfish (Pangasius hypophthalmus) using ELISA method. Serum catfish taken through a vein caudalis then injected sub-cutaneous in New Zealand White rabbits. ELISA method used is the indirect method and carried out to obtain the proper concentration RAC uses two types of antigen (Ag) A. hydrophila different in the form of pellet and supernatant. RAC concentration ratio used is $1: 50,1: 100,1: 200,1: 500,1: 1000$, and 1:5000. Parameters observed that the concentration of serum total protein and serum blood that has been dialyzed in catfish and rabbit blood. The results showed that the ratio between the RAC with PBS-T to the concentration of the best dilution is 1:5000 for antigen pellets and 1:200 for the supernatant antigens.

Keywords: ELISA, serum, rabbit anti-Catfish, Patin, Pangasius hypophthalmus

Bunyamin M, Mulyana dan Lusiastuti AM.2015. Produksi serum Rabbit Anti-Catfish terhadap penyakit Motile Aeromonas Septicemia (MAS) pada ikan Patin (Pangasius hypophthalmus. Jurnal Mina sains ... (...): ... - .... 


\section{PENDAHULUAN}

Ikan patin siam (Pangasius hyphothalmus) merupakan salah satu spesies budidaya perairan tawar utama yang banyak dibudidayakan di Indonesia disamping ikan mas, lele dan ikan nila dengan produksi pada tahun 2010 mencapai 104.574 ton (Dirjen Budidaya, 2011). Dalam dunia perikanan, ikan patin dikenal sebagai komoditi yang memiliki prospek cerah untuk dibudidayakan karena rasa dagingnya yang lezat dan gurih.Selain itu, ikan patin memiliki beberapa kelebihan lain seperti ukuran per individunya besar, mudah untuk dibudidayakan dan pertumbuhannya yang pesat (Normalina, 2007).

Penyakit merupakan salah satu faktor yang dapat menghambat dalam peningkatan produksi ikan secara intensif. Salah satu penyakit utama yang menyerang ikan menurut Angka (2004) adalah penyakit Motile Aeromonas Septicemia (MAS) atau disebut dengan penyakit bercak merah (red spot disease) yang disebabkan oleh bakteri Aeromonas hydrophila. Penyakit yang disebabkan oleh oleh bakteri $A$. hydrophila ini sering dihubungkan dengan perubahan kondisi lingkungan, tekanan-tekanan, termasuk kepadatan dalam populasi, temperatur tinggi, rendahnya oksigen terlarut, status nutrisi yang kurang baik, infeksi parasit dan kontribusi perubahan fisiologis (Hayes, 2000).

Diagnosa penyakit ini pada ikan lebih sulit untuk dilakukan. Gejalanya sering terkacaukan oleh trauma ikan yang disebabkan perkelahian antar ikan serta gejala klinis yang tidak spesifik tergantung dari spesies ikan dan lingkungan sekitarnya. Oleh karena itu diperlukan strategi pengendalian penyakit akuakultur yang lebih baik lagi antara lain dengan diagnosa penyakit yang cepat, tepat, dan akurat (Austin \& Austin, 1999 dalam Bijanti, 2011).

Pemeriksaan dapat dilakukan secara serologis dan klinis. Pemeriksaan secara serologis dapat dilakukan dengan menggunakan beberapa metode, seperti Aglutinasi (AG), Haemaglutination Inhibition (HI), Agar Gel Precipitation Test (AGPT),
Serum Netralisasi (SN), Enzyme Linked Immuno Sorbent Assay (ELISA) dan Flourescent Antibody Test (FAT) (Halimah, 2001). Dari beberapa metode di atas, metode ELISA merupakan metode yang paling banyak digunakan karena memiliki spesifisitas dan sensitifitas yang tinggi.

ELISA merupakan suatu uji serologik yang menggunakan kombinasi antara antibodi spesifik dengan enzim yang berfungsi sebagai pelacak keberadaan antigen.Adanya ikatan antibodi dan antigen dapat dideteksi melalui penambahan substrat yang akan terurai oleh enzim penanda tersebut dan dapat dilihat secara langsung melalui perubahan warna atau dengan spektrofotometer(Zainuddin, 2009).

Berdasarkan teknik produksinya antibodi terbagi atas dua yaitu antibodi poliklonal dan antibodi monoklonal. Harga antibodi monoklonal terbilang cukup mahal, sehingga diperlukan adanya penelitian yang bertujuan untuk membuat antibodi poliklonal dari serum kelinci spesifik untuk mendiagnosa penyakit MAS atau red spot disease. Diharapkan dengan tersedianya antibodi poliklonal tersebut dapat menggantikan antibodi poliklonal sebagai perangkat diagnostik. Dengan demikian, diagnosa yang tepat penyakit MAS pada ikan patin dapat dilakukan dengan baik.

Penelitian ini dilakukan dengan tujuan untuk memproduksi serum Rabbit Anticatfish (RAC) dan memperoleh kensentrasi terbaik sebagai bahan perangkat diagnostik.

\section{MATERI DAN METODE}

Penelitian ini dilaksanakan pada bulan Oktober 2012 sampai Februari 2013 di Balai Penelitian dan Pengembangan Budidaya Air Tawar (BPPBAT) Bogor.

Secara umum protein diukur menggunakan metode Bradford (1976).Darah ikan diambil dengan menyuntikkan spuit $3 \mathrm{~mL}$ ke bagian vena caudalis.Darah yang sudah diendapkan selama 24 jam dipisahkan dengan mengambil serum berupa cairan bening yang telah memisah menggunakan spuit 1 
mL. Serum yang masih berada pada endapan disentrifus dengan kecepatan 3000 rpm selama 15 menit pada suhu $4^{\circ} \mathrm{C}$.Serum yang dihasilkan dipisahkan kembali, disimpan pada suhu $-20^{\circ} \mathrm{C}$ untuk diproses lebih lanjut.

Sebelum serum siap digunakan untuk proses produksi antibodi poliklonal pada kelinci, serum ikan diproses terlebih dahulu dalam beberapa proses tahapan pemurnian untuk mendapatkan protein spesifik. Tahapan pertama adalah mengisolasi serum ikan ke dalam bentuk murni dengan metode presipitasi amonium sulfat. Tahapan purifikasi serum dilakukan dengan penambahan ammonium sulfat jenuh ke dalam serum dengan konsentrasi kejenuhan $100 \%$ dan dihitung menggunakan kalkulator ammonium sulfat. Dari $175 \mathrm{~mL}$ serum ikan patin, dilakukan beberapa kali proses penambahan ammonium sulfat. 15 mL serum ikan patin ditambahkan $10,75 \mathrm{gr}$ ammonium sulfat pada suhu $4^{0} \mathrm{C}$, presentasi kejenuhan yang diinginkan adalah 100\% dengan presentasi kejenuhan awal $0 \%$. Volume akhir setelah penambahan 10,75 gram ammonium sulfat ke dalam $15 \mathrm{~mL}$ serum adalah $20,71 \mathrm{~mL}$.

Serum dari ikan patin dimasukkan ke dalam beaker glass sebanyak 15 ml.Serum tersebut ditambahkan ammonium sulfat dan distirrer 24 jampada suhu $4^{\circ} \mathrm{C}$ (di dalam refrigerator). Setelah itu disentrifus 3.000 rpm, selama 30 menit pada suhu $4^{\circ} \mathrm{C}$. Presipitat (endapan) yang dihasilkan dilarutkan ke dalam $5 \mathrm{ml}$ buffer karbonatbikarbonat ( $\mathrm{pH} 9,6)$, kemudian disentrifus 3.000 rpm selama 30 menit pada suhu $4^{\circ} \mathrm{C}$. Endapan yang dihasilkan dikumpulkan dan volumenya dibuat menjadi $2 \mathrm{~mL}$ dengan penambahan buffer karbonat-bikarbonat. Selanjutnya $2 \mathrm{~mL}$ larutan tersebut disimpan pada suhu $-20^{\circ} \mathrm{C}$ untuk proses pemurnian.

Proses pemurnian dilakukan dengan memasukkan larutan hasil stirer 24 jam ke dalam membran dialisis.Membran dialisis tersebut terlebih dahulu direndam menggunakanPBS (pH 7,2) selama 24 jam. Selanjutnya membran dialisis diikat menggunakan benang dan direndam ke dalam PBS pH $(7,2)$ selama 72 jam pada suhu $4^{\circ} \mathrm{C}$. Setelah inkubasi 72 jam larutan PBS diambil $\pm 2 \mathrm{~mL}$ untuk direaksikan dengan $\mathrm{BaCl}_{2} 10 \%$ sebanyak 5 tetes, jika masih terdapat endapan putih berarti masih terdapat ammonium sulfat, dan proses dialisis dilanjutkan selama 24 jam.Uji BaCl2kembali dilakukan sampai tidak terbentuk endapan, hasil pemurnian disimpan pada suhu $-20^{\circ} \mathrm{C}$ untuk diinjeksikan ke kelinci.

Imunisasi pada kelinci dilakukan dengan injeksi secara subcutan menggunakan campuran IgG dan adjuvant seperti pada Tabel 1.Pengambilan darah dilakukan setelah 14 hari penyuntikan akhir selesai dilakukan.Darah yang dihasilkan disimpan dalam refrigerator pada suhu $4^{\circ} \mathrm{C}$ selama 24 jam, kemudian serum dipisahkan dengan mengambil cairan bening yang telah memisah.Serum yang dihasilkan diestimasi total proteinnya menggunakan metode Bradford dan dipurifikasi menggunakan metode purifikasi imunoglobulin seperti pada ikan patin. 
Tabel 1. Jadwal imunisasi pada kelinci

\begin{tabular}{|c|c|c|c|}
\hline $\begin{array}{c}\text { Hari } \\
\text { Ke- }\end{array}$ & $\begin{array}{c}\text { Volume } \\
\text { IgG + Adjuvant }\end{array}$ & Keterangan & Perbandingan \\
\hline 0 & $\begin{array}{c}0,2 \mathrm{~mL}+0,2 \\
\mathrm{~mL}\end{array}$ & $\begin{array}{l}\text { Ig G + Freund's } \\
\text { Complete } \\
\text { Adjuvant }\end{array}$ & $1: 1$ \\
\hline 3 & $\begin{array}{c}0,4 \mathrm{~mL}+0,4 \\
\mathrm{~mL}\end{array}$ & $\begin{array}{l}\text { Ig G + Freund's } \\
\text { Complete } \\
\text { Adjuvant }\end{array}$ & $1: 1$ \\
\hline 7 & $\begin{array}{c}0,6 \mathrm{~mL}+0,6 \\
\mathrm{~mL}\end{array}$ & $\begin{array}{l}\text { Ig G + Freund's } \\
\text { Complete } \\
\text { Adjuvant }\end{array}$ & $1: 1$ \\
\hline 9 & $\begin{array}{c}0,8 \mathrm{~mL}+0,4 \\
\mathrm{~mL}\end{array}$ & $\begin{array}{l}\text { Ig G + Freund's } \\
\text { Complete } \\
\text { Adjuvant }\end{array}$ & $2: 1$ \\
\hline 13 & $\begin{array}{c}1,0 \mathrm{~mL}+0,5 \\
\mathrm{~mL}\end{array}$ & $\begin{array}{l}\text { Ig G + Freund's } \\
\text { Complete } \\
\text { Adjuvant }\end{array}$ & $2: 1$ \\
\hline 15 & $\begin{array}{c}2,0 \mathrm{~mL}+2,0 \\
\mathrm{~mL}\end{array}$ & $\begin{array}{l}\text { Ig G + Freund's } \\
\text { Incomplete } \\
\text { Adjuvant }\end{array}$ & $1: 1$ \\
\hline
\end{tabular}

Penentuan titer antibodi yang berasal dari serum kelinci yang diimunisasi dilakukan mengggunakan metode indirect ELISA.Antigen untuk proses ELISA dibuat dari bakteri Aeromonas hydrophiladengan kode $\mathrm{AH}_{26}$. Bakteri tersebut dibarukan kembali dan diperbanyak pada media TSA dan diinkubasi pada suhu $28^{\circ} \mathrm{C}$ selama 24 jam. Setelah inkubasi dipindah-biakkan pada media salin $0,845 \%$ satu petri ke dalam $10 \mathrm{~mL}$ media salin, kemudian disonikasi pada $45 \mathrm{~Hz}$ selama 5 menit dalam keadaan dingin (onice). Bakteri dalam media salin yang sudah disonikasi disentrifus selama 60 menit dengan kecepatan 3000 rpm dalam suhu $4^{\circ}$ C.Endapan (pellet) dan supernatan dipisahkan, endapan dilarutkan kembali dalam media salin 0,845\%.

Tahapan yang dilakukan dalam uji ini diantaranya memasukkan $100 \mu \mathrm{l}$ antigen ditambah buffer karbonat-bikarbonat dengan $\mathrm{pH}$ 9,6 ke dalam mikroplate, kemudian dilakukan inkubasi 24 jam pada suhu $4^{\circ} \mathrm{C}$. Antigen yang dimasukkan ke dalam mikroplate terdiri dari dua kategori yaitu untuk antigen pellet dan antigen supernatan.Setelah diinkubasi larutan tersebut kemudian dibuang dan mikrotiter plate dicuci menggunakan PBS-TpH 7,4, kemudian ditambahkan 3\% BSA sebanyak $200 \mu \mathrm{l}$ dan diinkubasi selama satu jam pada suhu $25^{\circ} \mathrm{C}$. Larutan dibuang kembali dan mikroplate dicuci kembali menggunakan PBS-T pH 7,4. Selanjutnya ditambahkan 100 $\mu$ PBS-T pH 7,2 dan antibodi sampel (1:50, dengan PBS-T pH 7,2) sebanyak $100 \mu \mathrm{l}$, kemudian dilakukan serial dilution dan diinkubasi selama satu jam pada suhu $25^{\circ} \mathrm{C}$. Larutan dibuang dan mikrotiter plate dicuci dengan PBS-T pH 7,4.

Tahap selanjutnya adalah penambahan RACberbagai konsentrasi dengan PBS-T pH 7,2 sebanyak $100 \mu \mathrm{l}$ dan diinkubasi selama satu jam pada suhu $25^{\circ} \mathrm{C}$. Perbandingan konsentrasi RAC dengan PBS-T yang digunakan adalah sebagai berikut:

A. Perbandingan konsentrasi RAC : PBS-T dalam uji ELISA $=1: 50$

B. Perbandingan konsentrasi RAC : PBS-T dalam uji ELISA $=1: 100$

C. Perbandingan konsentrasi RAC : PBS-T dalam uji ELISA = $1: 200$

D. Perbandingan konsentrasi RAC : PBS-T dalam uji ELISA $=1: 500$

E. Perbandingan konsentrasi RAC : PBS-T dalam uji ELISA = $1: 1000$

F. Perbandingan konsentrasi RAC : PBS-T dalam uji ELISA = $1: 5000$.

Selanjutnya larutan dibuang kembali dan mikrotiter plate dicuci menggunakan PBS-T pH 7,4, kemudian ditambahkan enzim peroksidase conjugate anti-rabbit IgG dengan perbandingan 1:5000 antara enzim peroksidase dengan PBS-T pH 7,2 sebanyak $100 \mu \mathrm{l}$ dan diinkubasi selama satu jam, pada suhu $25^{\circ} \mathrm{C}$. Selanjutnya larutan dibuang dan mikrotiter plate kembali dicuci menggunakan PBS-T pH 7,4 kemudian ditambahkanTMB-ELISA $100 \mu \mathrm{l}$ dan diinkubasi selama 20 menit pada suhu $25^{\circ} \mathrm{C}$. Untuk blanko ditambahkan terlebih dahulu $100 \mu \mathrm{l}, 1 \mathrm{M} \mathrm{H} \mathrm{H}_{2} \mathrm{SO}_{4}$ diinkubasi selama 20 menit kemudian ditambahkan TMB.Sumur yang dijadikan blanko pada mikroplate adalah lubang pertama.Selanjutnya reaksi dihentikan dengan menambahkan $100 \mu \mathrm{l}$, $1 \mathrm{M} \mathrm{H}_{2} \mathrm{SO}_{4}$. Tahap terakhir adalah pembacaan OD menggunakan ELISA reader. 


\section{Analisis Data}

Data pengambilan darah dan pemisahan serum, data estimasi total protein serum, total protein setelah purifikasi ikan patin dan kelinci dianalisa secara deskriptif. Untuk mendapatkan konsentrasi ELISA yang tepat pada uji ELISA data yang diperoleh diolah dengan membandingkan antara berbagai perbandingan konsentrasi RAC.

\section{HASIL DAN PEMBAHASAN}

Dari ikan patin $32 \mathrm{~kg}$ yang memiliki berat rata-rata 450 - 500 gram, darah diambil rata-rata 5 - $6 \mathrm{~mL}$ per ekor ikan menghasilkan darah 330,7 mL. Setelah dilakukan pemisahan antara darah dan serum diperoleh serum murni sebanyak 192,6 mL.

Purifikasi serum dilakukan untuk memperoleh spesifisitas dan kemurnian Immunoglobulin (Ig).Kemurnian maupun spesifitas imunoglobulin dapat ditingkatkan dengan menghilangkan protein serum yang tidak diinginkan. Penelitian ini menggunakan ammonium sulfat $100 \%$ berdasarkan kadar jenuhnya. Konsentrasi $100 \%$ dianggap lebih dari cukup untuk dapat memisahkan protein sekaligus tetap mempertahankan aktivitas protein yang dimiliki oleh serum. Apabila kemurnian suatu protein bertambah maka konsentrasinya akan berkurang. Ketika suatu larutan garam dengan konsentrasi tinggi dan mengandung banyak ion seperti ion amonium $\left(\mathrm{NH}_{4}{ }^{+}\right)$dan ion sulfat $\left(\mathrm{SO}_{4}{ }^{2-}\right)$ ditambahkan ke dalam larutan yang mengandung protein, maka larutan tersebut akan bersaing dengan protein untuk mengikat molekul air (Heymant, 1995). Air akan berpindah dan berikatan dengan garam, sehingga kelarutan protein akan berkurang, menyebabkan pengendapan protein. Protein yang mengendap mempunyai afinitas yang lebih baik terhadap molekul protein lain daripada dengan molekul air (Harlow dan Lane 1988 dalam Ramlah, 2008). Kebanyakan antibodi akan mengendap pada kondisi 50\% jenuh. Kelemahan dari pengendapan dengan menggunakan amonium sulfat ini adalah protein yang diinginkan, misalnya antibodi, tidak didapatkan dalam keadaan murni dan masih terkontaminasi oleh protein-protein dengan berat molekul tinggi lainnya. Oleh karena itu, pengendapan dengan sulfat tidak dapat digunakan sebagai metode tunggal, tetapi harus dikombinasikan dengan metode lain agar diperoleh antibodi yang murni (Adyawati, 2003).

Hasil endapan yang dihasilkan dari proses penambahan ammonium sulfat ditambahkan buffer karbonat-bikarbonat sebanyak $5 \mathrm{~mL}$. Selanjutnya dilakukan sentrifugasi untuk mengendapkan kembali dan hasilnya ditambahkan kembali buffer karbonat-bikarbonat sebanyak $2 \mathrm{~mL}$ untuk proses dialisis. Serum sebanyak 188,9 mL dipurifikasi 13 kali sehingga diperoleh sebanyak $26 \mathrm{~mL}$ atau 13,76 \% yang mengendap dan didialisis untuk mendapatkan protein serum murni.

Di dalam suspensi yang dihasilkan pada proses di atas masih terdapat kandungan garam ammonium sulfat, untuk menghilangkan kandungan tersebut, maka dilakukan proses dialisis menggunakan PBS pH 7,2 selama 72 jam pada suhu $4^{\circ} \mathrm{C}$. Dalam sampel yang terkumpul diperkirakan masih banyak mengandung garam dengan konsentrasi yang cukup tinggi, oleh karena itu dilakukan dialisis untuk menukar buffer yang dimiliki oleh sampel dengan buffer yang tidak mengandung garam sama sekali. Hal ini dilakukan agar sampel dapat disimpan dalam waktu lama tanpa adanya kemungkinan terjadinya penurunan aktivitas protein (Rizkiani, 2006). IgM yang telah diperoleh ditempatkan dalam membran (kantung dialisis) selektif permeabel yang direndam dalam PBS maka molekul-molekul garam akan keluar melalui pori-pori kantung secara bertahap hingga konsentrasi garam di dalam dan diluar menjadi sama. Partikel yang berat molekul besar akan tetap dalam kantung dialisis sebaliknya partikel yang berat molekulnya kecil akan berdifusi keluar dari kantung dialisis (Harlow and Lane, 1988 dalam Ramlah, 2008). Proses dialisis ini dilakukan pada suhu $4^{\circ} \mathrm{C}$ selama 48 jam. Hasil purifikasi serum $26 \mathrm{~mL}$ di dianalisis sebanyak 2 kali menghasilkan serum 
protein murni $15 \mathrm{~mL}$ atau sebanyak 57,7 \% yang bisa diimunisasi pada kelinci.

\section{Estimasi Total Protein Serum dan Total Protein Hasil Purifikasi}

Untuk mengetahui kuantitas protein pada serum ikan dan hasil dialisis dilakukan pemeriksaan kandungan protein IgM dengan menggunakan metode Bradford dan dibaca dengan spektrofotometer pada panjang gelombang $595 \mathrm{~nm}$.Menurut Tort et al. (2003) immunoglobulin yang terdapat ikan teleostei terdiri dari IgM dan IgD. IgM merupakan immunoglobulin utama yang pertama dihasilkan dalam respons imun primer (Jawetz et al., 1998). IgM merupakan kira-kira $10 \%$ Ig serum dengan berat molekul 970.000. Sampel yang diuji berupa serum yang diambil dari ikan dan serum yang sudah dilakukan proses purifikasi. Berdasarkan hasil uji Bradford, kuantitas protein dapat dilihat pada Tabel 2 .

Tabel 2. Kandungan protein dalam sampel serum ikan patin

\begin{tabular}{ccc}
\hline \multirow{2}{*}{ Nama Sampel } & \multicolumn{2}{c}{ Kuantitas Protein } \\
\cline { 2 - 3 } & $\mathbf{P p m}$ & $\mathbf{g} / \mathbf{m L}$ \\
\hline Serum ikan patin & 260 & 0,733 \\
Serum hasil dialisis & 183,5 & 0,004 \\
\hline
\end{tabular}

IgM yang ada pada serum ikan patin dan serum yang sudah dipurifikasi memiliki perbedaan kuantitasnya.Pada penelitian ini, kuantitas protein yang ditemukan pada serum ikan patin adalah sebanyak 0,733 gram $/ \mathrm{mL}$ dan serum yang sudah didialisis $0,004 \mathrm{gram} / \mathrm{mL}$ atau sekitar $0,55 \%$.Hasil tersebut menunjukkan bahwa protein di dalam serum memiliki kuantitas protein lebih besar jika dibandingkan dengan serum yang sudah dilakukan proses pemurnian sampai tahap dialisis. Kuantitas protein sampel serum hasil dialisis sebanyak 70,5 \% dari sampel serum ikan patin dalam ppm. Kuantitas protein dalam sampel tersebut diperoleh dari penghitungan rataan ulangan sampel yang dikurangi dengan rataan ulangan blanko, kemudian dimasukkan ke dalam persamaan yang diperoleh dari kurva standar protein.

\section{Imunisasi Pada Kelinci}

Setelah dilakukan proses purifikasi serum dan pengujian total protein pada hasil purifikasi. Hasil purifikasi tersebut diimunisasikan pada kelinciselama 4 minggu.Dua minggu setelah imunisasi terakhir, darah diambil dari kelinci.

Produksi antibodi pada kelinci dapat dirangsang jika antigen terlebih dahulu diemulsikan dengan suatu adjuvan. Adjuvan yang paling umum digunakan adalah Freund'scompleteadjuvant dan Freund's incomplete adjuvant. Adjuvan merupakan substansi yang apabila disuntikkan bersama-sama dengan antigen akan menambah produksi antibodi dan juga berfungsi memperlambat pengeluaran antigen ke dalam tubuh. Berbagai macam substansi dengan komposisi kimiawi yang berbeda-beda telah dijumpai memilliki efek adjuvan. Substansi semacam itu meliputi alumunium dan garam-garam alumunium lainnya, natrium alginate, endotoksin bakteri, dan suspense air dalam minyak dengan atau tanpa mikrobakteri yang telah dimatikan.Adjuvan Freund's terdiri dari minyak mineral, zat pengemulsi, dan Mycobacterium tuberculosis yang telah dimatikan.Freund's complete adjuvant dan Freund's incomplete adjuvant hanya berbeda dalam hal ada tidaknya bakteri tersebut yang dapat menambah aktivitasnya. Adanya minyak mendorong terjadinya reaksi inflamasi lokal dan pembentukan jaringan granuloma di sekitar tempat suntikan.Antigen yang berada di dalam granuloma ini perlahan-lahan keluar ke dalam tubuh dan menyediakan rangsangan antigenik yang lama (Rizkiani 2006). Menurut Baratawidjaya (2006), bila antigen tertentu dimasukkan ke dalam sistem imun hewan percobaan, semua sel B yang mengenal banyak epitop pada antigen akan dirangsang dan memproduksi antibodi. Darah yang diambil dari hewan tersebut mengandung antibodi yang multipel yang akan bereaksi dengan epitop. Serum tersebut disebut poliklonal oleh karena mengandung produk yang berasal dari banyak klon sel B. Antibodi selalu bersifat 
spesifik terhadap antigen tertentu, demikian juga dengan penelitian ini, penyuntikan menggunakan protein dari serum patin akan menghasilkan antibodi poliklonal terhadap antigen ikan patin.

\section{Koleksi dan Purifikasi Serum Kelinci}

Kelinci yang sudah diimunisasi dan dipelihara selama dua minggu. Setelah imunisasi terakhir dilakukan pengambilan darah. Dari hasil pengambilan darah kelinci diperoleh sebanyak $50 \mathrm{~mL}$ dari dua kali pengambilan.Setelah dilakukan pemisahan antara darah dan serum diperoleh sebanyak 23,5 mL serum. Produksi serum pada kelinci menghasilkan $47 \%$ dari total darah, hal ini berbeda dengan ikan yang mampu menghasilkan serum sebanyak 58,24\% dari total darah.

Serum yang dihasilkan tersebut dilakukan proses purifikasi dan dialisis seperti yang dilakukan pada metode purifikasi serum ikan patin. Sebanyak 23,5 $\mathrm{mL}$ serum yang dipurifikasi dan didialisis menghasilkan sebanyak $5 \mathrm{~mL}$ atau $21,27 \%$ dari total serum yang akan digunakan untuk deteksi menggunakan metode ELISA.

\section{Estimasi Total Protein Serum Kelinci dan Total Protein Hasil Purifikasi}

Proses pengukuran total protein serum kelinci dan total protein hasil purifikasi sama halnya dengan pengukuran yang dilakukan pada serum dan hasil purifikasi serum ikan patin, yaitu menggunakan metode Bradford. Hasil pengujian total protein serum dan proses purifikasi dapat dilihat pada Tabel 3 .

Tabel 3.Total protein serum kelinci

\begin{tabular}{ccc}
\hline \multirow{2}{*}{ Nama Sampel } & \multicolumn{2}{c}{ Kuantitas Protein } \\
\cline { 2 - 3 } & $\mathbf{P p m}$ & $\mathbf{g} / \mathbf{m L}$ \\
\hline Serum Kelinci & 440 & 1,241 \\
Serum hasil & 50 & 0,141 \\
dialisis & & \\
\hline
\end{tabular}

Setelah dilakukan pengukuran konsentrasi protein di dalam serum kelinci dan serum yang telah dipurifikasi menggunakan metode Bradford didapatkan konsentrasi protein pada serum sebanyak 1,241 $\mathrm{g} / \mathrm{mL}$, sementara setelah dianalisis diperoleh konsentrasi protein sebanyak $0,141 \mathrm{~g} / \mathrm{mL}$ atau $11,36 \%$ dari konsentrasi serum kelinci. Hal ini dikarenakan pada serum kelinci masih terdapat banyak protein di dalamnya, sementara setelah proses purifikasi, protein yang diperoleh adalah protein spesifik yaitu IgG. IgG adalah antibodi utama dalam respon sekunder dan merupakan pertahanan inang yang penting terhadap bakteri yang terbungkus oleh virus-virus (Jawetz et al., 1998). Menurut Tizard (1988), IgG adalah imunoglobulin yang terdapat dalam konsentrasi tertinggi dalam serum dan strukturnya dapat dipakai sebagai model bagi imunoglobulin yang lain. IgG mempunyai berat molekul 180.000 Dalton.

\section{Uji ELISA}

Metode atau konfigurasi yang digunakan dalam penelitian ini adalah metode ELISA tidak langsung (indirect ELISA).Komponen yang dibutuhkan pada Indirect ELISA adalah antibodi, RAC, antibodi sampel, Peroksidase Conjugate anti-rabbit IgG, TMB-ELISA, PBS$\mathrm{T}$ dan $\mathrm{H}_{2} \mathrm{SO}_{4}$.

Percobaan ELISA yang dilakukan meliputi perbandingan antara RACyang telah diproduksi pada kelinci dengan larutan pencuci (PBS-Tween $\mathrm{pH}$ 7,2). Perbandingan ini diuji untuk mengetahui hasil pembacaan terbaik pada ELISA reader yang dapat dijadikan acuan untuk perbandingan antara RAC dengan PBS-T pada saat deteksi menggunakan metode ELISA. Perbandingan berbagai perbandingan yang digunakan dapat dilihat Gambar 1. 


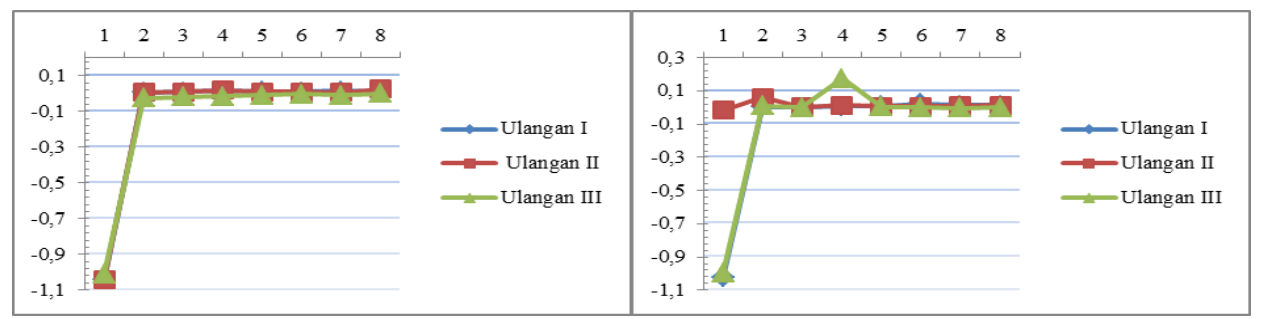

(A)

(B)

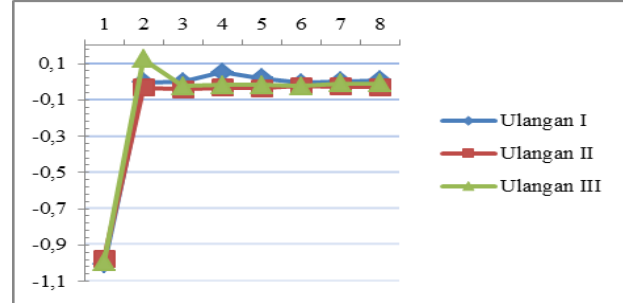

(C)

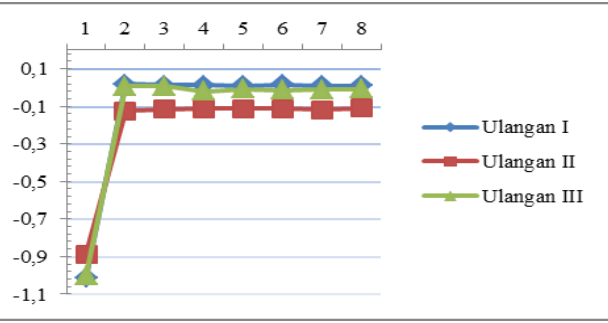

(E)

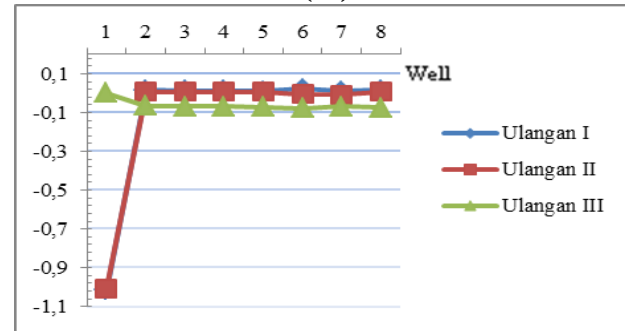

(G)

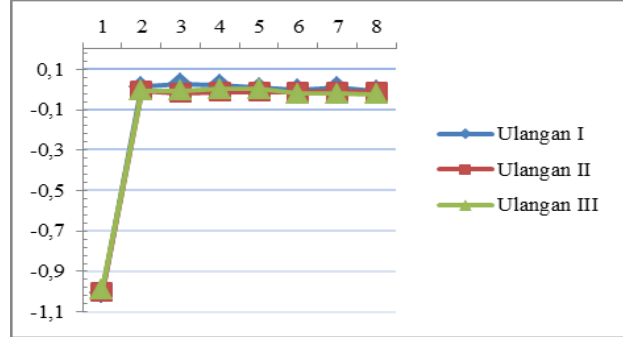

(I)

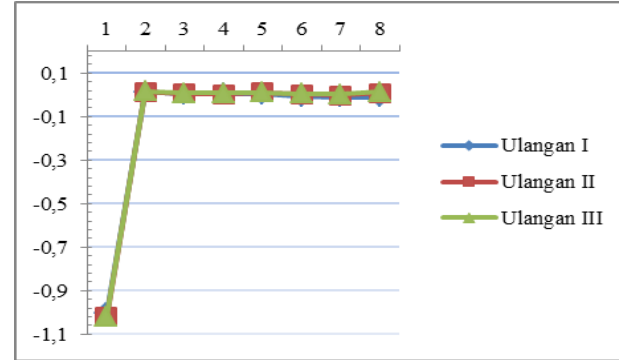

(K)

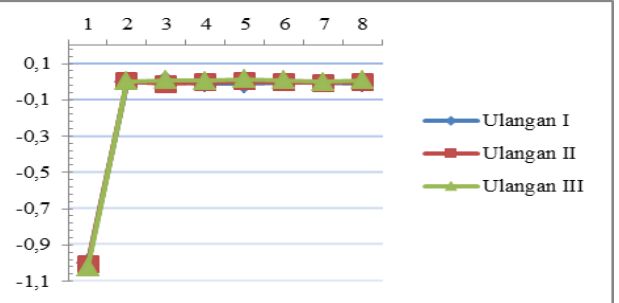

(D)

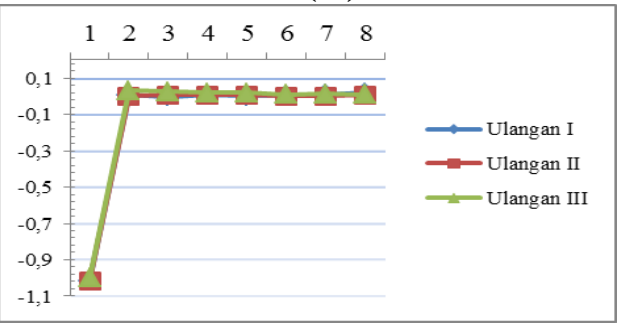

(F)

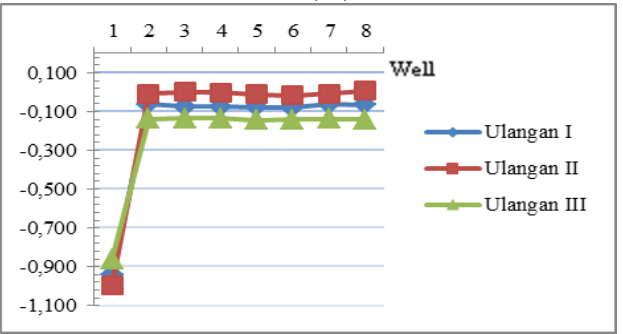

(H)

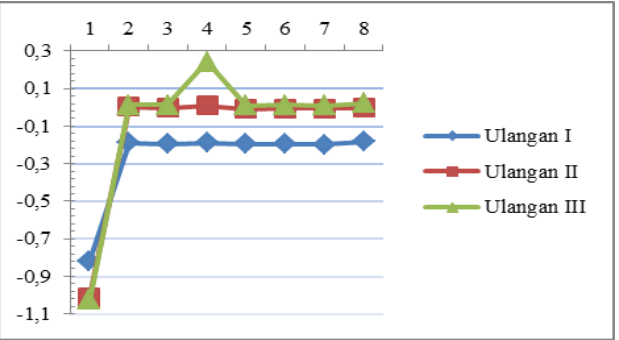

(J)

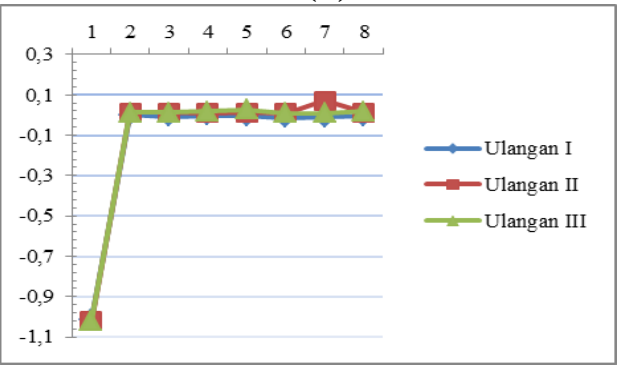

(L)

Gambar 1. Konsentrasi RAC; menggunakan antigen pelet (A) 1:50, (C) 1:100, (E) 1:200, (G) 1:500, (I) 1:1000, (K) 1:5000; menggunakan antigen supernatan; (B) 1:50, (D) 1:100, (F) 1:200, (H) 1:500, (J) 1:1000, (L) 1:5000 
Hasil pengukuran menggunakan ELISA reader terhadap perbandingan RAC dengan PBS-T menggunakan dua jenis antigen yaitu antigen pellet dan antigen supernatan dari bakteri Aeromonas hydrophila menunjukkan nilai kerapatan optik (optical density) terbaik pada perbandingan 1:200 untuk antigen supernatan dan 1:5000 untuk antigen pellet. Hal ini ditunjukkan dengan nilai kerapatan optik pada kedua perbandingan ini yang cenderung tidak mengalami peningkatan dan penurunan grafik yang cukup tinggi bila dibandingkan dengan perbandingan lain baik dari antigen pellet maupun antigen supernatan.

Nilai kerapatan optik pelet 1:200 memiliki kisaran pembacaan yang tidak terlalu besar jika dibandingkan dengan perbandingan 1:50, 1:100, 1:500, 1:100, dan 1:5000. Jika semua hasil pembacaan ELISA reader dibandingkan, maka perbandingan RAC + PBS-T 1:200 lebih bagus hasilnya daripada yang lain. Nilai kerapatan optik yang terbaca pada ELISA reader cenderung tidak ada peningkatan angka yang tinggi bila dibandingkan dengan pengenceran lain.

Pada metode indirect ELISA, plat dilapisi dengan antigen yaitu protein konjugat.Antibodi dan sampel/standar diinkubasi secara bersamaan, kemudian dimasukkan ke dalam lubang plat yang berisi antigen. Seperti halnya ELISA kompetitif langsung, kompetisi akan terjadi antara standar dan sampel untuk berikatan dengan antibodi. Setelah pencucian ditambahkan antibodi sekunder yang dilabel dengan enzim. Adanya reaksi komplek antara antigen dengan antibodi akan memberikan warna setelah penambahan substrat, yang dapat diukur dengan menggunakan ELISA reader (Spektrofotometer) (Maryam, 2007).

Pelapisan antigen ataupun antibodi terjadi secara adsorpsi pasif ke permukaan mikroplat karena adanya interaksi hidrofobik antara protein nonpolar dengan matrik plastik. Interaksi ini dipengaruhi oleh muatan protein dimana tiap-tiap protein memiliki konstanta pengikatan yang berbeda-beda. Reaksi antara antigen dan antibodi dipengaruhi oleh faktor intrinsik diantaranya temperatur, distribusi waktu inkubasi dan $\mathrm{pH}$ (kondisi buffer). Umumnya temperatur yang digunakan adalah $37^{\circ} \mathrm{C}$, temperatur ruang dan $4^{\circ} \mathrm{C}$. Memperpanjang waktu inkubasi antigen dapat menurunkan reaktivitas, karena ada pengaruh pelapisan berlebihan. Waktu inkubasi yang diperlukan agar terjadi $90 \%$ adsorbsi adalah minimal 26 jam inkubasi. Untuk mudahnya bekerja maka mikroplat dibiarkan dilapisi selama semalam pada suhu $4^{\circ} \mathrm{C}$ atau suhu kamar atau pada suhu $37^{\circ} \mathrm{C}$ selama 1-3 jam (Crowther, 1995).

\section{KESIMPULAN}

Koleksi serum ikan patin sebanyak 63 ekor dengan berat rata-rata 450-500 gram diperoleh sebanyak 330,7 mL darah dan menjadi 192,6 mL serum. Setelah proses purifikasi dihasilkan 26 $\mathrm{mL}$ dari presipitasi amonium sulfat dan $15 \mathrm{~mL}$ setelah dialisis.

Imunisasi pada kelinci dilakukan secara sub kutan, antibodi yang diperoleh dari hasil purifikasi disuntikkan dengan terlebih dahulu dicampur dengan adjuvant.

Uji ELISA yang dilakukan untuk mengetahui konsentrasi yang tepat untuk pengenceran antara RAC dengan PBS-T menghasilkan konsentrasi pengenceran yang terbaik yaitu antigen pelet adalah 1:5000, sedangkan untuk antigen supernatan adalah 1:200. 


\section{DAFTAR PUSTAKA}

Adyawati M. 2003. Produksi Antibodi Poliklonal Kambing Terhadap Canine Parvovirus Tipe 2 (CPV-2) Untuk Pengembangan Bahan Perangkat Diagnostik.Skripsi. Fakultas Kedokteran Hewan IPB. Bogor.

Angka SL, Priosoeryanto BP, Lay BW, Harris E. 2004. Penyakit Motile Aeromonad Septicaemia Pada Ikan Lele Dumbo (Clarias sp.): Upaya Pencegahan dan Pengobatannya Dengan Fitofarmaka. Forum Pascasarjana. IPB. Bogor.

Baratawidjaja KG. 2006. Imunologi Dasar Edisi ke tujuh. Balai Penerbit Fakultas Kedokteran Universitas Indonesia. Jakarta.

Bijanti R, Gandul M, Wiwik T, 2011. Antigenesity Protein of Aeromonas hydrophila caused ulce desease on Goldfish (Cyprinus carpio Linn.) Using Indirect ELISA technique. Faculty of Veterinary Medicine, Airlangga University. Surabaya.

Crowther JR. 1995. ELISA Theory and Practice. Totowa, New Jersey: Institute for Animal Health, Woking, UK. 42: 38-39.

Dirjen Budidaya. 2011. Statistik Perikanan Budidaya Indonesia. Kementrian Kelautan dan Perikanan. Ditjen. Perikanan Budidaya.

Heymant JM. 1995. Purifikasi Imunoglobulin. Dalam: Teknologi ELISA dalam Diagnosis dan Penelitian (Penterjemah: Artama WT, Editor Burgess GW). Yogyakarta: UGM Press. Hal: 33-49.

Hayes J. 2000. springtearmproject. oregonstateuniversity.net/aeromona shydrophila.net /html.
Jawetz E, Melnick JL, Adelberg EA. 1998. Mikrobiologi Kedokteran. Edisi 20. Alih Bahasa: Edin Nugroho dan RF Maulany. Jakarta: Penerbit Buku Kedokteran EGC.

Maryam R. 2007. Metode Deteksi Mikotoksin. Balai Penelitian Veteriner. vol 7: 20-21.

Normalina I. 2007. Pemanfaatan Ekstrak Bawang Putih (Allium sativum) Untuk Pencegahan dan Pengobatan Pada Ikan Patin (Pangasiodon hypophthalmus) yang diinfeksi Aeromonas hydrophila. Skripsi. IPB Bogor.

Ramlah. 2008. Purifikasi dan Karakterisasi Immunoglobulin $Y$ (IgY) Spesifik KHV Dari Serum Ayam Single Comb Brown Leghorn. Skripsi. FKH IPB Bogor.

Rizkiani F. 2006. Produksi Antibodi Poliklonal Oleh Toksin Insektisida Photorhabdus spp. Dan Deteksinya Dengan Teknik Nitrocellulose Membrane - Enzyme-Linked Immuno Sorbent Assay (NCM-ELISA). Skripsi. Fakultas MIPA, IPB. Bogor.

Tizard IR. 1988. Pengantar Imunologi Veteriner. Penerjemah Soehardjo Hardjosworo. Airlangga University Press.

Tort L, Balasch JC, Mackenzie S. 2003. Fish Immune System. A Crossroads Between Innate and Adaptive Responses. Immunologia 22 (3) : 277-286.

Zainuddin N. 2009. Kajian Penggunaan ELISA Sebagai Uji Cepat Dalam Mendeteksi Salmonella spp Pada Hati Sapi Impor. Tesis. IPB. Bogor. 